\title{
Sebaran Ukuran Diameter Pohon untuk Menentukan Umur dan Regenerasi Hutan di Lahan Bera Womnowi, Manokwari
}

\author{
Slamet Arif Susanto ${ }^{122) *}$ \\ ${ }^{1)} J u r u s a n$ Biologi, Fakultas Matematika dan Ilmu Pengetahuan Alam, Universitas Papua, Jl. Gunung Salju Amban \\ Manokwari, Papua Barat, Indonesia \\ ${ }^{2)}$ Program Studi Biologi Tumbuhan Sekolah Pascasarjana IPB, Jln. Agathis Dramaga Bogor 16680 Jawa Barat, \\ Indonesia \\ ${ }^{*}$ Alamat korespondensi: arif_susanto@apps.ipb.ac.id
}

\begin{abstract}
ABSTRAK
Lahan bera telah menjadi bentuk ekosistem yang umum dijumpai di Papua dan memiliki peran untuk mengembalikan kesuburan tanah. Penelitian ini dilakukan dengan tujuan untuk mengukur dan mengidentifikasi sebaran ukuran diameter pohon di lahan bera Womnowi Sidey Manokwari Papua Barat. Pada lahan bera dengan luas 1 hektar dibuat subpetak berukuran 20 x 20 meter yang di dalamnya terdapat subpetak ukuran 10 x 10 meter, sehingga total subpetak berjumlah 25. Diameter pohon diukur secara langsung di lapangan pada ketinggian 1,3 meter dari permukaan tanah atau diameter pohon setinggi dada. Data dianalisis secara statistik deskriptif dan tabulasi untuk menentukan pola regenerasi vegetasi pohon. Hasil menunjukkan terdapat dominasi sebaran ukuran diameter pohon pada kelas-kelas tertentu, namun tetap menunjukkan kurva $\mathbf{J}$ terbalik sebagai ciri proses regenerasi hutan sekunder intermediet yang baik. Nilai korelasi yang tinggi antara jumlah individu perhektar dengan ukuran sebaran kelas diameter vegetasi pohon dominan berturut-turut yaitu Matoa (Pometia pinnata), Lansat (Lansium domesticum), Drakon (Dracontomelon dao), dan Binuang/kayu perahu (Octomeles sumatrana). o. sumatrana adalah jenis dominan yang memiliki ukuran diameter pohon terbesar. Secara klasik disimpulkan preferensi habitat jenis tumbuhan selama periode bera berperan dalam daya regenerasi dan memengaruhi sebaran ukuran diameter pohon.
\end{abstract}

Kata kunci: diameter pohon, lahan bera, Papua Barat, regenerasi hutan

\section{Distribution of Tree Diameter Sizes to Determine the Age and Forest Regeneration in} the Fallow Land Womnowi, Manokwari

\author{
Slamet Arif Susanto $\left.{ }^{122}\right)^{*}$ \\ ${ }^{1)}$ Department of Biology, Faculty of Mathematics and Natural Sciences, Universitas Papua, Jl. Gunung Salju Amban \\ Manokwari, West Papua, Indonesia \\ ${ }^{2)}$ Study Program Plant Biology Postgraduate IPB, Jl. Agathis Dramaga Campus Bogor 16680 West Java, Indonesia \\ *Corresponding author: arif_susanto@apps.ipb.ac.id
}

\begin{abstract}
Fallow land has become a form of ecosystem commonly found in Papua and has a role to restore soil fertility. The research was conducted with the aim of measuring and identifying the distribution of tree diameter sizes in the fallow land Womnowi Sidey Manokwari West Papua. In a fallow area of 1 hectare, a $20 \times 20$ meter sub-plot was made with a sub-plot measuring $10 \times 10$ meters, so the total sub-plot numbered 25. Tree diameter was measured directly in the field at 1.3 meters above ground level or tree diameter breast height. Data were analyzed descriptively statistic and tabulated to determine the pattern of regeneration of tree vegetation. The results show that there is a predominance of the distribution of tree diameter sizes in certain classes, but still shows a reversed $\mathbf{J}$ curve as a feature of good secondary intermediate forest regeneration processes. The high correlation value between the number of individuals per hectare and the size of the class distribution of the dominant tree vegetation diameter are Matoa (Pometia pinnata), Lansat (Lansium domesticum), Drakon (Dracontomelon dao), and Binuang/kayu perahu (Octomeles sumatrana). O. sumatrana is the dominant type that has the largest tree diameter. Classically, it is concluded that habitat preferences for plant species during fallow period play a role in the effort regeneration and affect the distribution of tree diameter.
\end{abstract}

Keywords: trees diameter, fallow land, Western Papua, forest regeneration 


\section{PENDAHULUAN}

Lahan bera telah menjadi bentuk ekosistem yang umum ditemui di Papua. Lahan bera memiliki peranan penting dalam ekosistem untuk mengembalikan kesuburan tanah. [1] menyatakan lahan bera merupakan bagian dari sistem perladangan berpindah, yang memiliki konsensus untuk meningkatkan kesuburan tanah setelah dua atau tiga kali masa tanam [2], [3]. Selama periode bera vegetasi memberikan kontribusi bagi kesuburan tanah, khususnya jenis legum (pemfiksasi Nitrogen) [4]. Kehadiran vegetasi alami di lahan bera di Papua Barat mencerminkan daya regenerasi, proses suksesi sekunder, karakteristik tanah, dan umur lahan [5]-[7]. Pengukuran keakuratan umur lahan dan pertumbuhan vegetasi pohon dapat dilakukan dengan menentukan dan mengidentifikasi sebaran ukuran diameter pohon sebagai parameter utama [8], [9].

Beberapa studi seperti [8]-[10] telah menunjukkan bahwa sebaran ukuran diameter pohon mengindikasikan umur dan karakteristik hutan sekunder (termasuk lahan bera). [8] menunjukkan bahwa ciri khas dari hutan sekunder muda dan menengah adalah memiliki sebaran ukuran diameter pohon yang tidak melebihi $50 \mathrm{~cm}$, berbeda dengan hutan 'dewasa' (berumur tidak diketahui atau $>50$ tahun) yang memiliki sebaran ukuran diameter terlengkap yakni $5 \geq 100 \mathrm{~cm}$. [9] menunjukkan kegiatan penebangan selektif mampu terindikasi dengan tidak hadirnya ukuran diameter pohon vegetasi pohon tertentu, sehingga merubah pola kurva J terbalik. Kurva $\mathrm{J}$ terbalik yang menunjukkan hubungan antara kelas diameter dengan jumlah individu juga ditemukan pada hutan campuran dan hutan tanaman di Gunung Salak Bogor [10]. Semakin besar kelas ukuran diameter pohon, maka semakin sedikit individu yang berada di kelas tersebut.

Karakteristik dan komposisi jenis vegetasi di lahan bera dapat terindikasi berdasarkan indeks nilai penting (INP) [7]. Namun nilai INP belum dapat menunjukkan karakteristik sebaran ukuran diameter pohon di lahan bera. Permasalahan dalam konteks pemberaan lahan adalah perubahan vegetasi yang sebenarnya eksistensi vegetasi tersebut bersifat temporer. Pendeknya periode bera di Papua diakibatkan oleh pertumbuhan penduduk yang tinggi dan berkurangnya lahan pertanian tradisional untuk permukiman [11]. Dalam konteks untuk meningkatkan kesuburan tanah [1], [4], memprediksi karbon tersimpan pada vegetasi [12], dan karakteristik bera [7], perlu diidentifikasi seluruh jenis vegetasi yang melingkupi lahan bera. Gambaran daya regenerasi pada hutan sekunder terlihat melalui sebaran ukuran diameter pohon [8], namun periode bera dapat menjadi lebih singkat akibat terbatasnya sumberdaya lahan dan sebaran ukuran diameter pohon belum teridentifikasi. Berdasarkan permasalahan tersebut di atas, maka tujuan penelitian ini adalah mengidentifikasi sebaran ukuran diameter pohon di lahan bera berumur 15 tahun di Womnowi Sidey Manokwari. Penelitian ini bermanfaat sebagai data awal sebaran ukuran diameter pohon di lahan bera milik petani tradisional di Womnowi Sidey Manokwari.

\section{METODE PENELITIAN}

Lokasi penelitian. Penelitian dilaksanakan di lahan bera berumur 15 tahun Womnowi Sidey Manokwari, alasan dipilih lahan bera tersebut karena lahan bera 15 tahun umumnya akan digunakan kembali sebagai lahan pertanian oleh masyarakat lokal di Womnowi Sidey Manokwari.Selain itu, hampir 60\% lahan bera di Papua berumur lebih dari 10 tahun[13]. Secara geografis, lokasi penelitian terletak pada koordinat $\mathrm{S} 0^{\circ} 48^{\prime} 17.2^{\prime \prime}-\mathrm{S} 0^{\circ} 48^{\prime} 10,2^{\prime \prime} \quad \mathrm{E} 133^{\circ} 28^{\prime} 59,2^{\prime \prime}-$ E133 $28^{\prime} 53.62^{\prime \prime}$ yang merupakan lahan bera dataran rendah $132 \mathrm{mdpl}$ serta diapit oleh Sungai Kasi dan Sungai Womnowi (Gambar 1). Suhu dan kelembaban udara yang tercatat selama penelitian berkisar pada rentang $27{ }^{\circ} \mathrm{C}$ dan $78 \%$.

Alat dan bahan yang digunakan adalah Global Positioning System (GPS), kompas, termohigrometer, tali tambang, meteran rol, buku saku, dan alat tulis. Bahan yang digunakan adalah seluruh jenis vegetasi pohon yang melingkupi lahan bera di Womnowi Sidey Manokwari.

Prosedur penelitian. Pendataan jenis pohon dilakukan pada 25 subpetak sampling dengan menggunakan metode direct continuous strip sampling [14], berdasarkan asumsi seluruh jenis pada lahan bera ikut terdata. Pada total luas lahan bera 1 hektar dibuat subpetak sampling berukuran $20 \times 20$ 
meter yang di dalamnya terdapat petak berukuran 10 x 10 meter. Ukuran petak 10 x 10 meter untuk pendataan fase tiang (diameter $10-19 \mathrm{~cm}$ ), dan petak $20 \times 20$ meter untuk fase pohon (diameter $\geq 20 \mathrm{~cm}$ ). Setiap jenis diukur diameter setinggi dada $(1,3$ meter dari permukaan tanah) [8], [9], yang teknik pengukurannya mengacu pada [15].

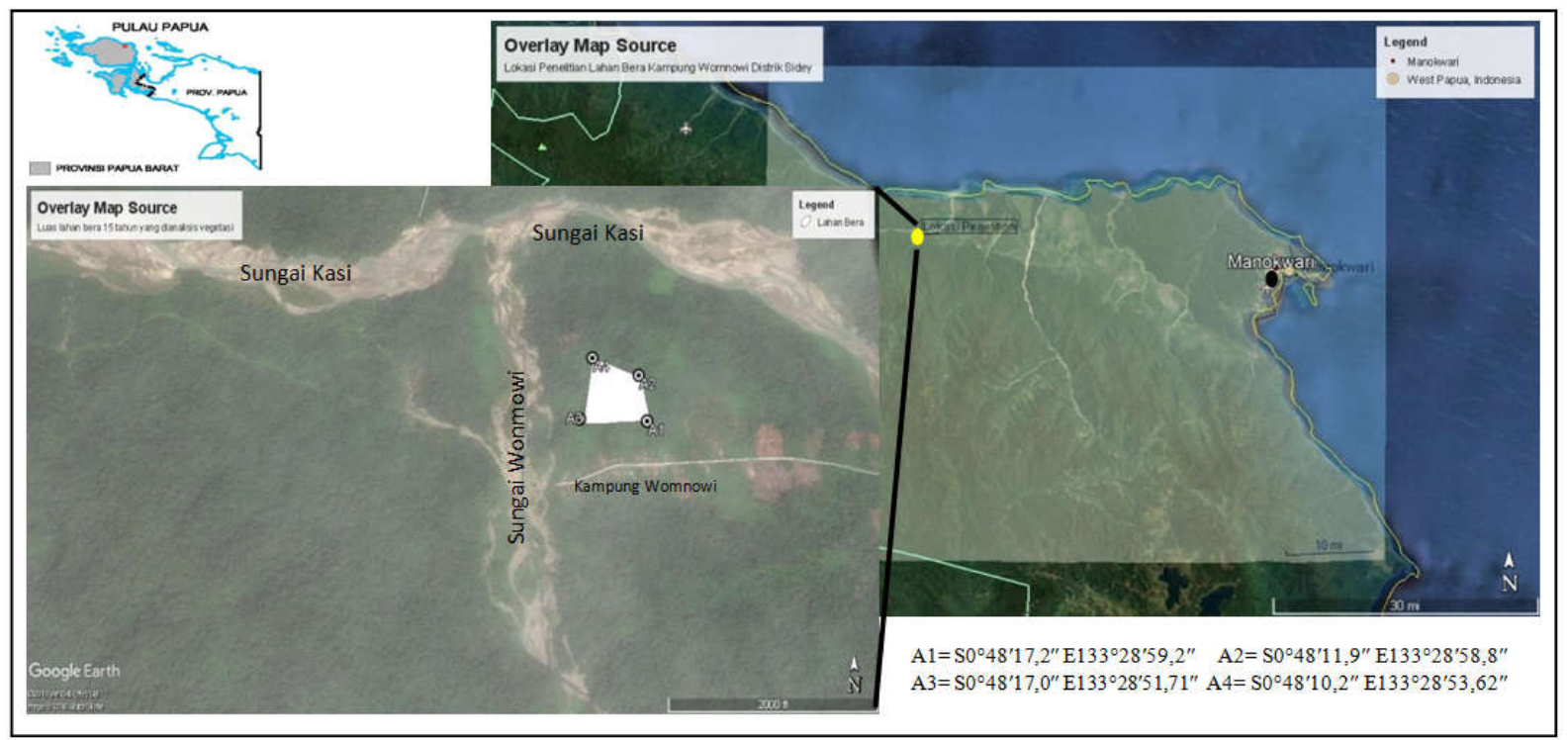

Gambar 1. Peta letak lokasi penelitian lahan bera 15 tahun di Womnowi Sidey Manokwari

Analisis data. Data dianalisis dengan menggunakan program Microsoft Office Excel 2007 dan dibuat dalam bentuk tabel distribusi frekuensi berdasarkan ukuran kelas diameter pohon mengacu pada[8]-[10]. Sebaran ukuran diameter vegetasi pohon dominan berdasarkan INP diinterpretasikan secara terpisah menggunakan analisis regresi linear sederhana untuk menentukan daya regenerasi dan pola kurva J terbalik dan di tampilkan dalam bentuk grafik.

\section{HASIL DAN PEMBAHASAN}

Hasil pengukuran sebaran diameter pohon pada 25 subpetak sampling di lahan bera berumur 15 tahun Womnowi Sidey Manokwari menunjukkan dominasi sebaran ukuran diameter pohon pada kelas-kelas tertentu (Tabel 1). Ciri khas hutan sekunder berumur 15 tahun tercermin pada tingginya sebaran ukuran diameter pohonpada fase tiang (poles) dan sangat jarang ditemukan sebaran ukuran diameter pohon di kelas diameter $>50$ $\mathrm{cm}$. Kecenderungan sebaran ukuran diameter pohon pada lahan bera berumur 15 tahun Womnowi Sidey Manokwari terakumulasi di kelas 10-49 cm (Tabel 1). Hasil ini menyerupai penelitian [8] bahwa sebaran ukuran diameter pohon di hutan sekunder intermediet (10-30 tahun) di daerah dataran rendah Papua New Guinea memiliki sebaran ukuran diameter pohon kurang dari $50 \mathrm{~cm}$. Vegetasi pohon juga memiliki nilai konservasi yang penting ditunjukkan pada Lampiran $1[16]$, khususnya nilai dominasi yang tinggi akibat dari ukuran diameter pohon.

Terdapat kesenjangan antara sebaran ukuran diameter pohon pada kelas 10-59 cm dengan kelas diameter pohon $>60 \mathrm{~cm}$, khususnya pada kelas 60-69 $\mathrm{cm}$. Pada luas area sampling 1 ha tidak ditemukan pohon berdiameter 60-69 cm, namun ditemukan kembali pohon pada kelas diameter $>70 \mathrm{~cm}$ bahkan melebihi $80 \mathrm{~cm}$ (Tabel 1). Hasil ini memberikan gambaran terdapat dua penjelasan yakni kecepatan pertumbuhan jenis di hutan sekunder (khususnya fast growing species) dan jenis yang memiliki diameter $>70 \mathrm{~cm}$ telah tumbuh sebelum proses pemberaan lahan atau sesaat sesudah pemberaan lahan. Tingginya jumlah kelas diameter pohon yang tergolong dalam kelompok 'pohon muda' (kelas diameter 10-20 cm) )tercermin pada Tabel 1. Hasil serupa ditemukan pada penelitian [17] di daerah Fef dan Bamusbama Tambrauw Papua Barat pada area sampling hutan yang tidak jauh dari area permukiman warga, dimana lebih dari $70 \%$ individu di dua area tersebut 
didominasi oleh pohon dengan diameter $<30$ $\mathrm{cm}$.

Jenis yang tergolong dalam kelas diameter teratas $(>70 \mathrm{~cm})$ seluruhnya adalah binuang atau kayu perahu (Octomeles sumatrana). Jenis tersebut tergolong dalam INP tertinggi fase tiang dan pohon (Lampiran 1), bahkan termasuk INP ketiga fase pohon dengan nilai dominasi relatif yang tinggi yang

Tabel 1. Gambaran umum sebaran ukuran diameter pohon di lahan bera berumur 15 tahun Womnowi Sidey Manokwari

\begin{tabular}{|c|c|c|c|c|c|c|c|c|}
\hline \multirow[t]{2}{*}{ Subpetak } & \multicolumn{8}{|c|}{ Diameter $(\mathrm{cm})$} \\
\hline & $10-19$ & $20-29$ & $30-39$ & $40-49$ & $50-59$ & $60-69$ & $70-79$ & $>80$ \\
\hline 1 & 6 & 2 & 2 & 2 & 1 & 0 & 0 & 0 \\
\hline 2 & 8 & 5 & 0 & 2 & 1 & 0 & 0 & 0 \\
\hline 3 & 4 & 5 & 3 & 2 & 0 & 0 & 0 & 0 \\
\hline 4 & 10 & 1 & 3 & 2 & 0 & 0 & 0 & 0 \\
\hline 5 & 6 & 6 & 2 & 0 & 2 & 0 & 0 & 0 \\
\hline 6 & 8 & 2 & 7 & 1 & 0 & 0 & 0 & 0 \\
\hline 7 & 6 & 4 & 3 & 3 & 0 & 0 & 0 & 0 \\
\hline 8 & 7 & 3 & 3 & 1 & 0 & 0 & 0 & 0 \\
\hline 9 & 5 & 2 & 4 & 2 & 0 & 0 & 0 & 0 \\
\hline 10 & 8 & 1 & 4 & 2 & 0 & 0 & 0 & 0 \\
\hline 11 & 8 & 5 & 0 & 0 & 0 & 0 & 1 & 0 \\
\hline 12 & 10 & 7 & 1 & 2 & 0 & 0 & 0 & 0 \\
\hline 13 & 11 & 7 & 3 & 0 & 0 & 0 & 0 & 0 \\
\hline 14 & 6 & 8 & 2 & 0 & 0 & 0 & 0 & 0 \\
\hline 15 & 8 & 7 & 2 & 0 & 0 & 0 & 0 & 0 \\
\hline 16 & 8 & 8 & 1 & 1 & 0 & 0 & 0 & 0 \\
\hline 17 & 8 & 5 & 2 & 1 & 0 & 0 & 0 & 0 \\
\hline 18 & 8 & 4 & 1 & 2 & 0 & 0 & 0 & 0 \\
\hline 19 & 8 & 3 & 2 & 0 & 0 & 0 & 0 & 0 \\
\hline 20 & 10 & 1 & 4 & 0 & 0 & 0 & 0 & 0 \\
\hline 21 & 6 & 7 & 2 & 0 & 0 & 0 & 0 & 0 \\
\hline 22 & 8 & 5 & 2 & 0 & 0 & 0 & 0 & 0 \\
\hline 23 & 7 & 5 & 1 & 0 & 0 & 0 & 0 & 0 \\
\hline 24 & 5 & 5 & 1 & 0 & 0 & 0 & 0 & 0 \\
\hline 25 & 5 & 4 & 1 & 0 & 0 & 0 & 0 & 1 \\
\hline Kumulatif & 184 & 112 & 56 & 23 & 4 & 0 & 1 & 1 \\
\hline $\begin{array}{l}\text { Rerata per } \\
\text { subpetak }\end{array}$ & 7 & 4 & 2 & $<1$ & $<1$ & 0 & $<1$ & $<1$ \\
\hline
\end{tabular}

memiliki status konservasi least concern (LC) [7], [16]. O. sumatrana merupakan ciri khas vegetasi di daerah dataran rendah tanah alluvial di Papua dengan ciri fast growing dan pertumbuhannya lebih cepat dibanding jenis lainnya [11]. Secara gradual pernyataan tersebut sesuai dengan penelitian ini, dimana pada lahan bera berumur 15 tahun (hutan sekunder), ditemukan jenis $O$. sumatrana dengan diameter pohon melebihi $70 \mathrm{~cm}$.
Preferensi habitat $O$. sumatrana mencerminkan tanah alluvial terkonfirmasi dalam penelitian ini, sehingga kecepatan pertumbuhan dari $O$. sumatrana untuk menghasilkan ukuran batang $>70 \mathrm{~cm}$ selama masa bera 15 tahun di lahan bera Womnowi Sidey Manokwari merupakan hal yang wajar dan realistik. Daya regenerasi O. sumatrana di bawah tegakkan pohon induknya sangat rendah [11], sehingga fase semai dan pancang dari $O$. sumatrana tidak termasuk 10 INP tertinggi [7]. 
O. sumatrana tergolong dalam kelompok short rotatation plantation dengan umur maksimal rotasi 15-25 tahun [18], [19] menunjukkan bahwa $O$. sumatrana mampu tumbuh dengan ukuran rerata ukuran diameter $4,267 \mathrm{~cm}$ setelah 12 bulan pasca tanam. Hasil tersebut lebih rendah dibanding jenis Ochroma pyramidale, namun lebih tinggi dibanding Nauclea orientalis, Ficus variegata, Anthocephalus cadamba, dan Anthocephalus macrophyllus.

Total kumulatif individu berdasarkan sebaran ukuran diameter pohon menunjukkan daya regenerasi dengan kurva $J$ terbalik (Gambar 2), sejalan dengan penelitian yang pernah dilakukan di Papua oleh [8], [17], [20] sehingga diindikasikan ekosistem lahan bera berumur 15 tahun di Womnowi Sidey Manokwari dalam kondisi yang relatif stabil dan baik. Hasil analisis secara statistik menunjukkan nilai $\mathrm{R}^{2}$ yang tinggi $\left(\mathrm{R}^{2}=0.946\right)$ (Gambar 2), memiliki arti semakin besar kelas ukuran diameter pohon, maka semakin sedikit individu yang menempati kelas tersebut. Pola kurva $\mathrm{J}$ terbalik dengan nilai $\mathrm{R}^{2}$ yang tinggi dapat dipengaruhi oleh daya regenerasi vegetasi pohon dominan [20], meskipun vegetasi pohon dominan pada penelitian ini tidak memiliki nilai $\mathrm{R}^{2}$ yang lebih tinggi (Gambar 2).

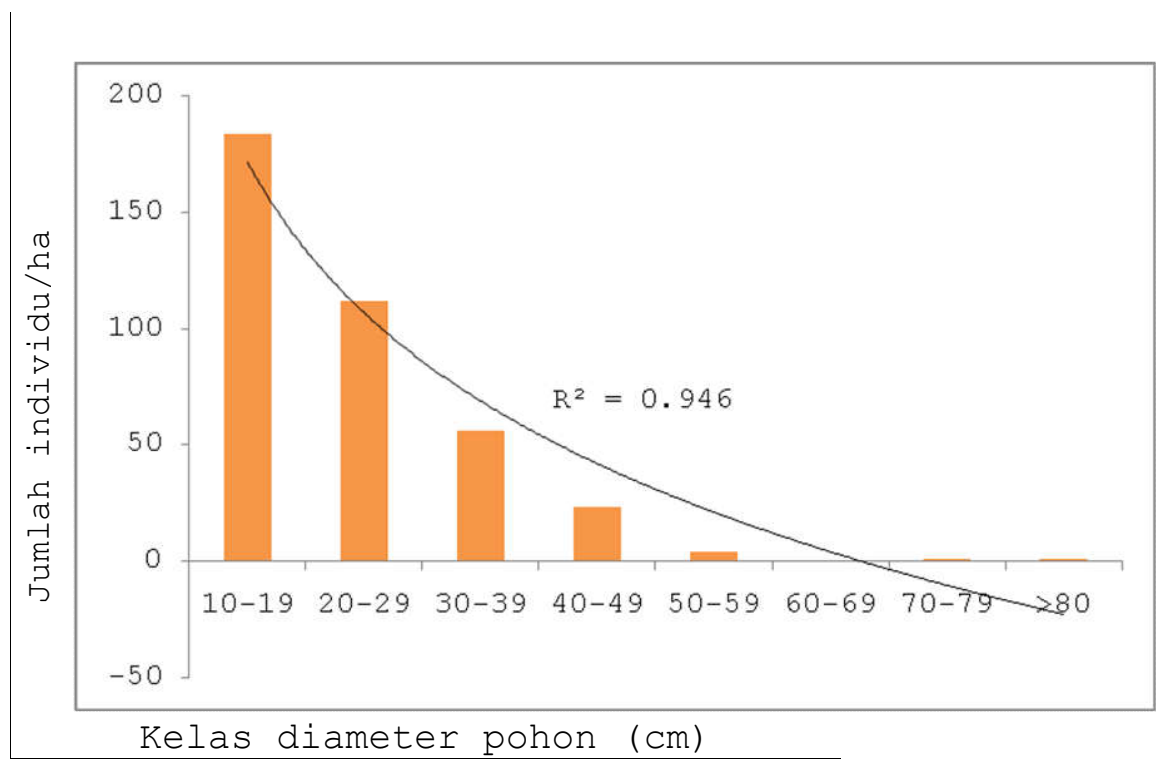

Gambar 2. Kumulatif individu berdasarkan sebaran ukuran diameter pohon di lahan bera 15 tahun Womnowi Sidey Manokwari

Jenis vegetasi pohon dominan menunjukkan daya regenerasi berbeda-beda (Gambar 3). P. pinnata memiliki INP tertinggi fase pohon (Gambar 3), [7] menunjukkan jumlah individu pada fase tiang (diameter 10$19 \mathrm{~cm}$ ) lebih rendah dibanding pada fase pohon (diameter $\geq 20 \mathrm{~cm}$ ), namun secara statistik memiliki nilai $\mathrm{R}^{2}(0.854)$ yang paling tinggi dibanding tiga jenis dominan lainnya. Hal ini sejalan dengan penelitian [7] dimana fase semai, pancang, dan tiang $P$. pinnata di lahan bera 15 tahun Womnowi Sidey Manokwari termasuk dalam 10 INP tertinggi (Gambar 4).

Regenerasi vegetasi pohon dominan diprediksi akan terjadi pergeseran di masa mendatang, khususnya pada jenis binuang/kayu putih (Octomeles sumatrana) dan Drakon (Dracontomelon dao) (Gambar 3). Hal ini diindikasikan dengan kedua jenis tersebut tidak mendominasi pada fase semai dan pancang. Lansat (Lansium domesticum) dan Matoa (Pometia pinnata) diduga akan tetap mendominasi lahan bera di Womnowi Sidey Manokwari, karena kedua jenis tersebut hadir dan mendominasi sepuluh INP tertinggi fase semai, pancang, dan tiang [7].

Sebaran ukuran diameter pohon tidak menunjukkan daya regenerasi yang sempurna, dimana tidak seluruh kelas terisi oleh individu tertentu (Gambar 3). O. sumatrana merupakan jenis dengan sebaran ukuran batang yang hampir lengkap, namun tidak memiliki pola kurva $\mathrm{J}$ terbalik dengan nilai $\mathrm{R}^{2}$ paling rendah (0.707), sehingga daya regenerasi jenis ini lebih rendah dibanding tiga jenis dominan 
lainnya. Drakon (Dracontomelon dao) adalah jenis dengan grafik menyerupai $O$. sumatrana, namun memiliki sebaran kelas yang sedikit dengan jumlah individu yang lebih banyak dan memiliki nilai $\mathrm{R}^{2}$ lebih tinggi $(0.778)$ dibanding $O$. sumatrana. Regenerasi jenis yang mencerminkan hal yang seharusnya ditemukan pada lansat (Lansium domesticum), dimana fase tiang (diameter 10-19 cm) memiliki jumlah individu lebih banyak dibanding dengan fase pohon.

Meskipun daya regenerasi $L$. domesticum sangat baik, tidak adanya individu pada kelas diameter pohon $>40 \mathrm{~cm}$ menyebabkan nilai $\mathrm{R}^{2}$ yang lebih rendah (0.807) dibanding matoa (Pometia pinnata), jenis L. domesticum termasuk dalam INP tertinggi fase semai, pancang, dan tiang bersama dengan jenis $P$. pinnata [7].

Terdapat dua hal dari interpretasi data dari Gambar 2, yakni sejarah penggunaan lahan (termasuk luasan area sampling), dan kecepatan pertumbuhan suatu jenis (termasuk dipengaruhi oleh daya toleransi terhadap cahaya). Asal usul lahan berpengaruh pada kehadiran jenis yang melingkupi suatu area, khususnya lahan bera. Gangguan secara alami maupun akibat aktivitas manusia (termasuk lahan bera), mengakibatkan hilangnya kanopi hutan, sehingga memberikan kesempatan bagi jenis untuk beregenerasi [21]. Kegiatan menghilangkan kanopi akibat penebangan hutan (logging) juga merubah komposisi floristik dari fase semai dan tumbuhan bawah, dimana dalam kondisi alami tidak berpengaruh, namun secara massif menyebabkan hilangnya jenis-jenis tertentu [20]. Area sampling yang cukup terbatas dan awal regenerasi tidak diketahui secara pasti menimbulkan disparitas pada sebaran ukuran diameter pohon di lahan bera Womnowi Sidey Manokwari.

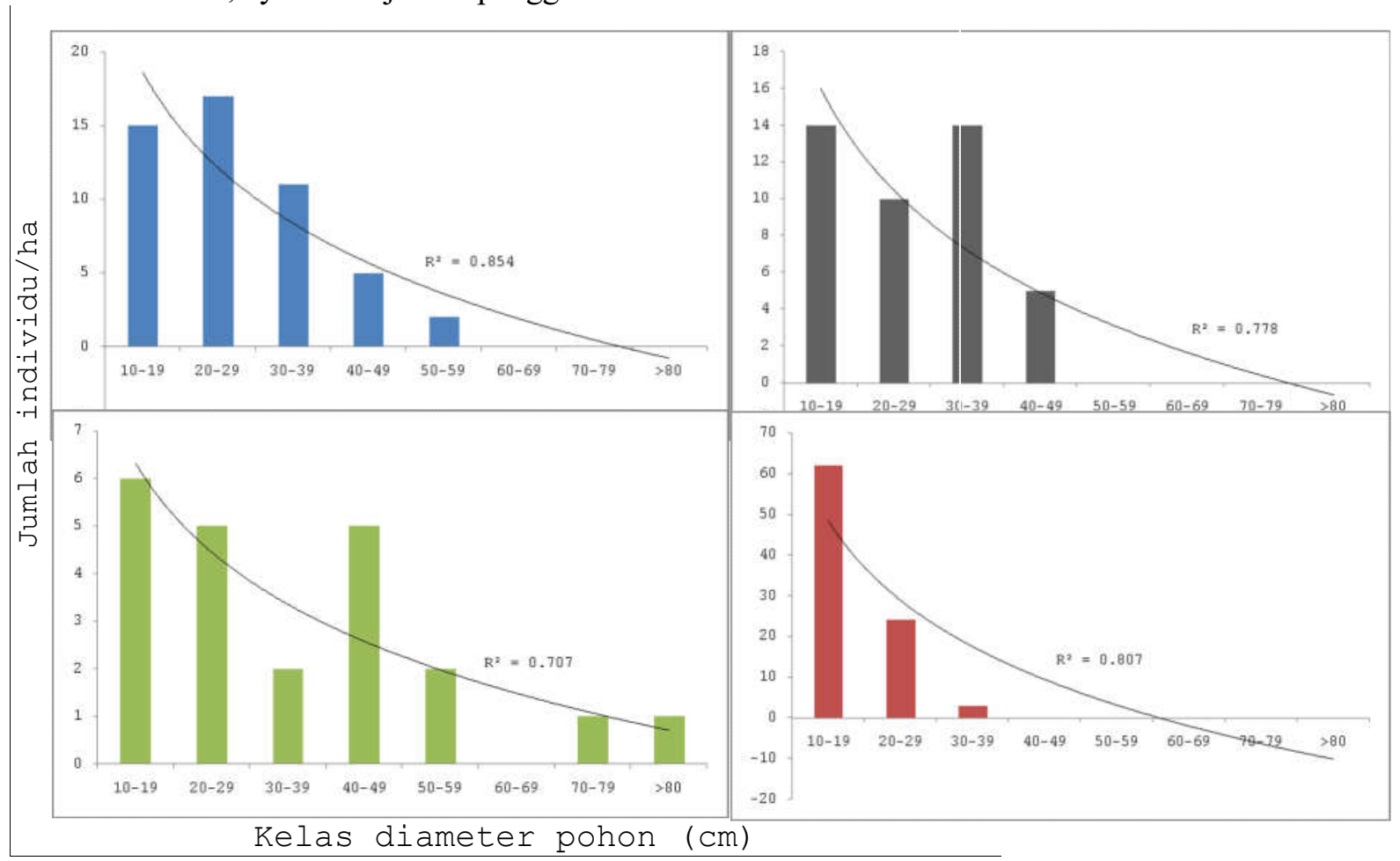

Gambar 3. Sebaran ukuran diameter pohon vegetasi dominan di lahan bera 15 tahun Womnowi Sidey Manokwari. Keterangan warna bar: biru=Pometia pinnata; hitam=Dracontomelon dao; hijau=Octomeles sumatrana; dan merah=Lansium domesticum. Semakin tinggi nilai $\mathrm{R}^{2}$, maka semakin baik daya regenerasi jenis tersebut. 


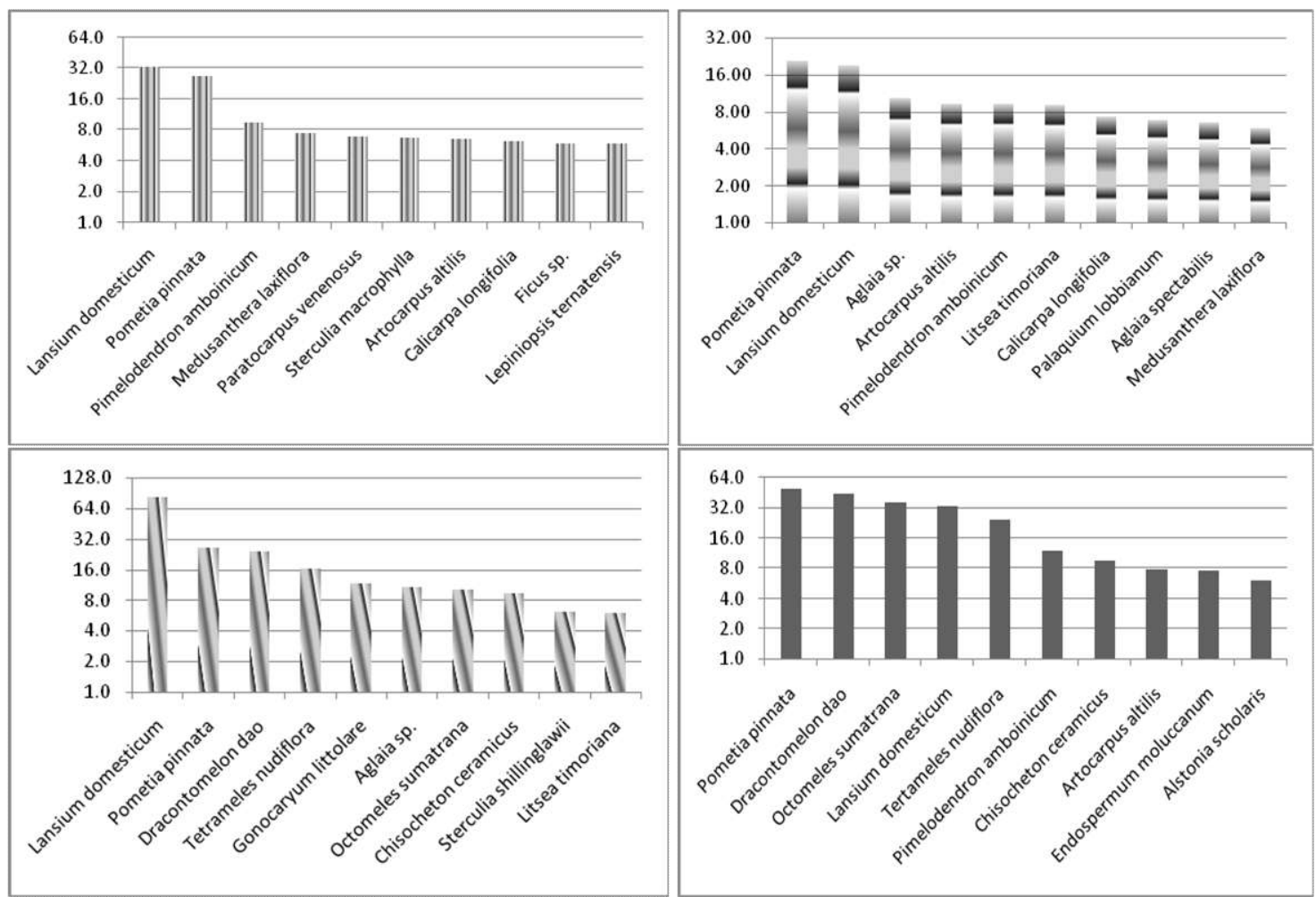

Gambar 4. Sepuluh INP fase semai hingga pohon pada lahan bera 15 tahun di Womnowi Sidey Manokwari (data diadaptasi dari [7])

\section{KESIMPULAN}

Sebaran ukuran diameter pohon di lahan bera berumur 15 tahun Womnowi Sidey Manokwari mampu mengindikasikan umur lahan dan daya regenerasi vegetasi pohon di masa mendatang. Lahan bera berumur 15 tahun Womnowi Sidey Manokwari merupakan hutan sekunder intermediet dengan akumulasi diameter pohon tersebar pada kelas 10-49 cm. Kumulatif individu dan jenis vegetasi pohon dominan berdasarkan kelas diameter pohon membentuk kurva $\mathrm{J}$ terbalik dengan regresi $\mathrm{R}^{2}$ yang tinggi mengindikasikan daya regenerasi hutan yang baik.

\section{UCAPAN TERIMA KASIH}

Terima kasih kepada Bapak Martinus Matabua sebagai pemilik lahan bera berumur 15 tahun Womnowi Sidey Manokwari dan sebagai guide di lapangan. Apresiasi yang luar biasa diberikan kepada Krisma Lekitoo M.Sc, Heru Joko Budirianto M.Si, dan Agatha C. Maturbongs, M.Sc. atas saran publikasi dan diskusi analisis data yang bermanfaat.

\section{DAFTAR PUSTAKA}

[1] Sanchez PA (1999) Improved fallows come of age in the tropics. Agroforestry System 47 (1-3): 3-12.

[2] Ruijter J, Agus F. (2004) Apa yang dimaksud dengan bera? World Agroforestry Centre 2004. http://www.worldagroforestry.org/sea/Pub lications/files/leaflet/LE0021-04.pdf.

Diakses: Juni 2019.

[3] Lininger K (2011) Small-scale farming and shifting cultivation. In: Union of Concerned Scientist (eds) The Root of the problem: What 's driving tropical deforestation today? UCS, Cambridge, $\mathrm{pp}$. 1-7.

[4] Szott LT, Palm CA, Davey CB (1994) Biomass and litter accumulation under managed and natural tropical fallows. Forest Ecology and Management 67 (2): 177-190.

[5] Budirianto HJ, Ratnawati S (2018) Struktur vegetasi lahan bera Kampung Bremi Pantai Utara Kabupaten Manokwari. In Prosiding Seminar Nasional MIPA UNIPA 3(1) pp. 115-126. 
[6] Budirianto HJ, Sianipar FRDN, Arobaya MO (2018) Identifikasi jenis vegetasi dominan di areal bekas kebun dan kebun di Kampung Ayambori Manokwari. Jurnal Natural 14 (1): 14-28.

[7] Susanto SA, Budirianto HJ, Maturbongs AC (2018) Komposisi jenis tumbuhan di tanah alluvial lahan bera diperkaya Womnowi, Distrik Sidey Manokwari. In Prosiding Seminar Nasional MIPA UNIPA 3 (1): 22-32.

[8] Whitfeld TJS, Lasky JR, Damas K, Sosanika G, Molem K, Montgomery RA (2014) Species richness, forest structure, and functional diversity during succession in the New Guinea Lowlands. Biotropica 46 (5): 538-548.

[9] Gonçalves FMP, Revermann R, Cachissapa MJ, Gomes AL, Aidar MPM (2018) Species diversity, population structure and regeneration of woody species in fallows and mature stands of tropical woodlands of Southeast Angola. Journal of Forestry Research 29 (6): 1569-1579.

[10] Wiharto M, Kusmana C, Prasetyo LB, Partomihardjo T (2008) Distribusi kelas diameter pohon pada berbagai tipe vegetasi di Gunung Salak, Bogor, Jawa Barat. Jurnal Ilmu Pertanian Indonesia 13 (2): 95-102.

[11] Marshall AJ, Beehler BM (2012) Ecology of Indonesian Papua Part Two. Tuttle Publishing pp. 492-530.

[12] Gao W, Huang S, Huang Y, Yue X, Ye G (2019) Effects of tree species on soil carbon and nitrogen stocks in a coastal sand dune of southern subtropical China. Vegetos 32 (2): 142-150.

[13] Allen B, Filer C (2015) Is the 'Bogeyman' Real? Shifting cultivation and the forests, Papua New Guinea. In: M. Cairns, J. Alcorn, C. Colfer, D. Russell, N. Royo (eds) Shifting cultivation and environmental change: Indigenous people, agriculture and forest conservation. Routledge, London, pp. 517-520.

[14] Lekitoo K, Khayati L (2019) Woody diversity plant and non-timber forest products potential in protected forest area of protected forest management unit model in Sorong City, West Papua. In Prosiding Seminar Nasional Masyarakat Biodiversitas Indonesia 5 (2) pp. 294-298.

[15] Badan Standardisasi Nasional/BSN (2011) Pengukuran dan penghitungan cadangan karbon-pengukuran lapangan untuk penaksiran cadangan karbon hutan (Ground based forest carbon accounting). BSN, Jakarta, p. 6.

[16] Susanto SA (2019) Status konservasi vegetasi di lahan bera Womnowi Sidey Manokwari (sebuah catatan kecil inventarisasi vegetasi di hutan sekunder Papua Barat). BIOMA Jurnal Biologi Makassar 4 (2): 107-120.

[17] Robiansyah I (2018) Diversity and biomass of tree species in Tambrauw, West Papua, Indonesia. Biodiversitas Journal Biological Diversity 19 (2): $377-$ 386.

[18] Hashim MN, Hazim M, Syafinie AM (2015) Strategic forest plantation establishment in Malaysia for future product development and utilization. In Proceeding of the Kuala Lumpur International Agriculture, Forestry and Plantation Conference pp. 236-240.

[19] Rachmat HH, Subiakto A, Susilowati A (2019) Genetic resources of fast-growing tree for rehabilitating upland area of deteriorated Saguling catchment, West Java, Indonesia. Biodiversitas Journal Biological Diversity 20 (2): 442-447.

[20] Pamoengkas P, Siregar IZ, Dwisutono AN (2018) Stand structure and species composition of Merbau in logged-over forest in Papua, Indonesia. Biodiversitas Journal Biological Diversity 19 (1): 163171.

[21] Chazdon RL (2003) Tropical forest recovery: legacies of human impact and natural disturbances. Perspective Plant Ecologi Evolutionand Systematic 6 (1-2): 51-71. 
Lampiran 1. Hasil analisis vegetasi pohon di lahan bera 15 tahun Womnowi Sidey Manokwari

\begin{tabular}{|c|c|c|c|c|c|}
\hline No & Nama Jenis & JI* & $\mathbf{J I}^{\wedge}$ & INP* & $\mathbf{I N P}^{\wedge}$ \\
\hline 1 & Aglaia odorata Lour. & 2 & 0 & 3.49 & 0.00 \\
\hline 2 & Aglaia sp. & 6 & 1 & 10.7 & 1.45 \\
\hline 3 & Aglaia spectabilis (Miq.) Jain \& Bennet. & 1 & 0 & 1.81 & 0.00 \\
\hline 4 & Alstonia scholaris (L.) R. Br. ${ }^{++}$ & 1 & 4 & 1.67 & 6.11 \\
\hline 5 & Antiaris toxicaria (Pers.) Leschen. & 1 & 2 & 1.74 & 3.08 \\
\hline 6 & Artocarpus altilis (Parkinson) Fosberg. & 3 & 5 & 5.14 & 7.99 \\
\hline 7 & Astronia hollrungii Cogn. & 1 & 0 & 1.81 & 0.00 \\
\hline 8 & Buchanania arborescens (B1.) Bl. & 0 & 1 & 0.00 & 1.92 \\
\hline 9 & Calophyllum soulattri Burm. f. & 2 & 0 & 3.21 & 0.00 \\
\hline 10 & Cananga odorata (Lam.) Hook. f. \& Thomson. & 0 & 1 & 0.00 & 1.67 \\
\hline 11 & Canarium hirsutum Willd. & 2 & 1 & 4.26 & 1.50 \\
\hline 12 & Cerbera floribunda K. Schum. & 0 & 1 & 0.00 & 1.45 \\
\hline 13 & Chisocheton ceramicus Miq. & 5 & 6 & 9.50 & 9.49 \\
\hline 14 & Decaspermum parviflorum (Lam.) A. J. Scott. & 1 & 0 & 2.17 & 0.00 \\
\hline 15 & Dendrocnide sinuata (B1.) Chew. & 1 & 0 & 1.67 & 0.00 \\
\hline 16 & Dracontomelon dao (Blanco) Merr. \& Rolfe. & 14 & 29 & 24.4 & 43.87 \\
\hline 17 & Drypetes globosa (Merr.) Pax \& K.Hoffm. & 0 & 1 & 0.00 & 1.53 \\
\hline 18 & Dysoxylum mollissimum $\mathrm{Bl}$ & 0 & 1 & 0.00 & 1.53 \\
\hline 19 & Endospermum moluccanum Becc. & 1 & 5 & 2.28 & 7.75 \\
\hline 20 & Melicope elleryana (F. Muell.) T.G. Hartley. & 2 & 0 & 3.55 & 0.00 \\
\hline 21 & Ficus nodosa Teijsm. \& Binn. & 1 & 1 & 1.67 & 1.45 \\
\hline 22 & Ficus pungens Reinw. ex Blume. & 1 & 0 & 1.67 & 0.00 \\
\hline 23 & Ficus trachypison K. Schum. ex K. Schum. \& Lauterb. & 1 & 0 & 1.67 & 0.00 \\
\hline 24 & Garcinia latissima Miq. & 1 & 0 & 1.81 & 0.00 \\
\hline 25 & Gmelina arborea Roxb. ex Sm. & 1 & 0 & 1.60 & 0.00 \\
\hline 26 & Gnetum gnemon L. & 1 & 0 & 1.60 & 0.00 \\
\hline 27 & Gomphandra globosa & 0 & 1 & 0.00 & 1.41 \\
\hline 28 & Goniothalamus sp. & 0 & 1 & 0.00 & 1.41 \\
\hline 29 & Gonocaryum litorale (Blume) Sleumer. & 6 & 3 & 11.6 & 5.35 \\
\hline 30 & Homalium foetidum (Roxb.) Benth. & 2 & 3 & 3.64 & 4.80 \\
\hline 31 & Horsfieldia irya (Gaertn.) Warb. & 1 & 0 & 1.60 & 0.00 \\
\hline 32 & Horsfieldia laevigata Warb. & 1 & 0 & 1.89 & 0.00 \\
\hline 33 & Intsia bijuga (Colebr.) Kuntze. & 1 & 0 & 1.81 & 0.00 \\
\hline 34 & Kokoona ochracea (Elmer) Merr. & 1 & 0 & 1.60 & 0.00 \\
\hline 35 & Koordersiodendron pinnatum (Blanco) Merr. & 0 & 1 & 0.00 & 1.48 \\
\hline 36 & Lansium domesticum Correa. & 62 & 27 & 83.3 & 33.1 \\
\hline 37 & Lepiniopsis ternatensis Valeton. & 1 & 0 & 1.74 & 0.00 \\
\hline 38 & Litsea ledermanii Tesch. & 0 & 2 & 0.00 & 2.82 \\
\hline
\end{tabular}




\begin{tabular}{|c|c|c|c|c|c|}
\hline 39 & Litsea timoriana Span. $^{++}$ & 3 & 4 & 6.02 & 5.98 \\
\hline 40 & Macaranga mappa (L.) Müll.Arg. & 1 & 0 & 1.67 & 0.00 \\
\hline 41 & Mangifera minor Blume. & 0 & 3 & 0.00 & 4.29 \\
\hline 42 & Maniltoa browneoides Harms. & 1 & 0 & 1.81 & 0.00 \\
\hline 43 & Medusanthera laxiflora (Miers) R. A. Howard & 1 & 0 & 1.74 & 0.00 \\
\hline 44 & $\begin{array}{l}\text { Melanolepis multiglandulosa (Reinw. ex Blume) Rchb. } \\
\text { \& Zoll. }\end{array}$ & 2 & 3 & 4.05 & 4.94 \\
\hline 45 & Melicope sp. & 0 & 1 & 0.00 & 1.61 \\
\hline 46 & Milliusa sp. & 1 & 0 & 1.60 & 0.00 \\
\hline 47 & Octomeles sumatrana Miq. $^{++}$ & 6 & 16 & 10.2 & 36.51 \\
\hline 48 & Palaquium lobbianum Burck. & 1 & 2 & 1.67 & 3.11 \\
\hline 49 & Parartocarpus venenosa (Zoll. \& Mor.) Becc. & 2 & 2 & 4.24 & 3.23 \\
\hline 50 & Picrasma javanica & 0 & 1 & 0.00 & 1.43 \\
\hline 51 & Pimelodendron amboinicum Hassk. & 3 & 8 & 5.21 & 12.15 \\
\hline 52 & Pisonia grandis $\mathrm{R} . \mathrm{Br}$. & 3 & 0 & 4.87 & 0.00 \\
\hline 53 & Maasia sumatrana (Miq.) et Mols. & 1 & 0 & 1.67 & 0.00 \\
\hline 54 & Polyscias nodosa (Blume.) Seem. & 1 & 0 & 1.98 & 0.00 \\
\hline 55 & Pometia pinnata J.J. Forst. \& G. Forst. & 15 & 35 & 26.0 & 48.98 \\
\hline 56 & Prainea limpato (Miq.) Beumee. ex K. Heyne. & 1 & 0 & 1.60 & 0.00 \\
\hline 57 & Pterygota horsfieldii (R.Br.) Kosterm. & 0 & 2 & 0.00 & 3.08 \\
\hline 58 & Premna serratifolia $\mathrm{L}$. & 1 & 0 & 1.67 & 0.00 \\
\hline 59 & Sterculia macrophylla Vent. & 1 & 3 & 1.89 & 4.66 \\
\hline 60 & Sterculia shillinglawii F.Muell. ${ }^{++}$ & 3 & 0 & 6.12 & 0.00 \\
\hline 61 & Syzygium versteegii (Lauterb.) Merr. \& Perry. & 1 & 1 & 1.60 & 1.64 \\
\hline 62 & Teijsmanniodendron bogoriense Koord. & 1 & 0 & 1.81 & 0.00 \\
\hline 63 & Terminalia complanata K. Schum. & 0 & 1 & 0.00 & 1.48 \\
\hline 64 & Tetrameles nudiflora $\mathrm{R} . \mathrm{Br}^{++}$ & 8 & 16 & 16.3 & 24.34 \\
\hline \multirow[t]{2}{*}{65} & Trichospermum javanicum B1. & 1 & 1 & 1.74 & 1.43 \\
\hline & Total & 182 & 196 & 300 & 300 \\
\hline
\end{tabular}

Sumber: [16]

Keterangan: *fase tiang; ^fase pohon; ${ }^{\text {huruf }}=$ INP tertinggi; ${ }^{\text {numeral }}=$ sepuluh INP tertinggi fase tiang; numeral $=$ sepuluh INP tertinggi fase pohon [7]; ${ }^{++}=$terkategori dalam least concern (LC) menurut International Union for Conservation of Nature Resources (IUCN). 